\title{
Peran Media Sosial dalam Menunjang Kinerja dan Popularitas Institusi Pendidikan Tinggi
}

\author{
Hafidhah*, Miftahol Arifin**, Mohammad Herli*** \\ *Hafidhah adalah dosen program studi akuntansi Universitas Wiraraja \\ Email: hafidhah@wiraraja.ac.id \\ ** Miftahol Arifin adalah dosen program studi manajemen Universitas Wiraraja \\ Email: miftaholarifin@wiraraja.ac.id \\ ** Mohammad Herli adalah dosen program studi akuntansi Universitas Wiraraja dan \\ Mahasiswa Program Doktor Ilmu Akuntansi Universitas Airlangga \\ Email: mohammad.herli-2017@feb.unair.ac.id
}

\begin{abstract}
Abstrak
Media sosial telah menjadi perhatian utama bagi semua orang termasuk akademisi, terutama karena fleksibilitasnya sebagai alat komunikasi. Keberadaannya menjadikan sebagai sumber yang sangat signifikan dari informasi di dunia saat ini. Beberapa orang bahkan mungkin bergantung pada situs media sosial untuk mendapatkan berita terbaru bahkan sebelum muncul di saluran berita tradisional seperti televisi, radio, atau media massa. Media sosial telah mengubah cara orang dalam berkomunikasi, berbagi konten, berinteraksi, dan berkolaborasi. Sejalan dengan itu, penelitian ini bertujuan untuk menganalisis peran media sosial dalam menunjang kinerja dan popularitas institusi pendidikan tinggi. Kami menggunakan data jumlah postingan, viewer, follower, dan subscriber pada masing-masing media sosial yang dikelola oleh pendidikan tinggi dan menganalisisnya menggunakan regresi untuk melihat hubungannya dengan kinerja dan popularitas pendidikan tinggi di Jawa Timur. Hasil penelitian menunjukkan bahwa adopsi sosial tweeter dan YouTube berdampak pada kinerja pendidikan tinggi yaitu jumlah mahasiswa. Kami juga menemukan bahwa peningkatan jumlah visitor pada website resmi institusi pendidikan tinggi dipengaruhi oleh jumlah postingan, viewer, dan follower pada akun media sosial Facebook, Instagram, dan tweeter. Dilihat dari perspektif manajemen strategis, kami melihat adanya peluang bagi universitas untuk mengelola media sosialnya secara efektif. Hal tersebut Akan memberikan dampak terhadap peningkatan popularitas di dunia maya dan kinerja institusi.
\end{abstract}

Kata Kunci: media sosial; kinerja; pendidikan tinggi

\section{PENDAHULUAN}

Popularitas media sosial dikalangan pelajar dan mahasiswa mengalami peningkatan secara drastis dalam beberapa tahun terakhir, dan lembaga pendidikan tinggi merespons kemajuan tersebut dengan memaksimalkan penggunaan media sosial untuk terhubung dengan stakeholder (Cao, Ajjan, Hong, \& Le, 2018; Lenartz, 2012). 
Hal ini pada gilirannya menyebabkan tekanan pada institusi pendidikan tinggi untuk memanfaatkan media sosial di dalam dan di luar kelas agar dapat terhubung dengan mahasiswa, alumni, dan pihak lain di eksternal kampus (Figueira, 2018). Tentu saja ada manfaat potensial untuk lembaga pendidikan tinggi yang dapat diperoleh dari adopsi media sosial tersebut. Namun, laju perubahan ini telah mengakibatkan banyak lembaga tidak menetapkan standar dalam pengelolaan media social (Grimaldi \& Fernandez, 2019). Sehingga dampak adopsi media social oleh pendidikan tinggi tidak begitu Nampak dalam menunjang kinerja manajemen pendidikan tinggi (Hamid, Ijab, Sulaiman, Md. Anwar, \& Norman, 2017; O’Connor, Schmidt, \& Drouin, 2016).

Penelitian ini menguji secara empiris penggunaan social media oleh pendidikan tinggi dan dampaknya pada kinerja organisasi. Penelitian ini akan mengungkap peran penting social media sebagai kekuatan baru institusi pendidikan tinggi dalam menarik mahasiswa baru dan menciptakan value bagi institusi pendidikan tinggi. Sosial media menjadi hal yang tidak dapat ditinggalkan oleh hampir setiap orang. Social media mewarnai kehidupan seseorang dalam keseharian nya (Vrontis, El Nemar, Ouwaida, \& Shams, 2018a). Hal ini terbukti dengan naiknya angka pengguna media social pada setiap tahunnya (Bochenek \& Blili, 2013). Sosial media dapat menghubungkan orang, organisasi, perusahaan, dan masyarakat (Eom, Hwang, \& Kim, 2018). Beberapa decade terakhir ini, semenjak lahirnya Facebook, Instagram, YouTube, Skype, dan Twitter, institusi privat maupun nonprofit menggunakan social media sebagai cara baru untuk dapat terhubung, menjangkau, dan berkomunikasi dengan berbagai pemangku kepentingan (Martin, 2017). Social media memberikan kemudahan bagi organisasi untuk bersosialisasi dan menginformasikan kinerja yang dicapainya kepada pihak luar dengan cara yang lebih efektif dan efisien (Corcoran \& Duane, 2017; Gálvez-Rodríguez, Caba-Pérez, \& López-Godoy, 2016).

Kemajuan media sosial semakin menarik perhatian dunia, karena besarnya potensi dan kegunaannya. Tidak heran ketika banyak lembaga bisnis memusatkan perhatian kepada media social dalam mencapai tujuan perusahaan. Saat ini, media sosial telah bergerak lebih cepat diluar penggunaan pribadi (Ahmed, Ahmad, Ahmad, \& Zakaria, 2019). Social Media semakin menjadi andalan sejumlah organisasi sebagai alat untuk berbagi pengetahuan dan komunikasi dengan berbagai cara yang berbeda. Social media bertransformasi secara cepat menjadi alat komunikasi, pengetahuan, dan berkolaborasi.

Social media menciptakan saluran baru pertukaran informasi antara stakeholder dan berpotensi untuk meningkatkan pangsa pasar perusahaan dalam jangka panjang. Hal ini menjadikan beberapa perusahaan maupun organisasi nirlaba memfokuskan 
pengelolaan social media sebagai cara baru meningkatkan nilai perusahaan (Fujita, Harrigan, Roy, \& Soutar, 2019; Mangold \& Faulds, 2009; Wilburn \& Wilburn, 2015). Sehingga, untuk mewujudkan manfaat yang nyata dari social media tersebut, para ilmuwan menyarankan agar perusahaan mengadopsi social media dan mengelolanya dengan baik. Berbagai bukti empiris telah menunjukkan peran penting social media dalam meningkatkan nilai perusahaan (Akmese, Aras, \& Akmese, 2016; Mokhtar, 2017) dan kinerja perusahaan (Chen, Hung, \& Wang, 2018; Tarutė \& Gatautis, 2014). Alalwan (2018), menemukan adanya hubungan antara adopsi social media oleh perusahaan dengan sikap pelanggan serta kualitas informasi yang tersedia di website dan loyalitas pelanggan. Adopsi social media yang dikelola organisasi berhubungan positif dengan inovasi, pihak eksternal organisasi memberikan input yang positif kepada organisasi melalui media social (Corral de Zubielqui, Fryges, \& Jones, 2019). Selain itu, penggunaan social media ada organisasi sector publik memiliki hubungan positif yang kuat dengan tingkat kepuasan dan tingkat kepercayaan dalam pemerintahan (Porumbescu, 2016). Adopsi media sosial tidak selamanya memberikan dampak positif bagi perusahaan, Stamati, Papadopoulos, \& Anagnostopoulos, (2015) melaporkan bahwa media sosial tidak selalu memberikan dampak positif bagi organisasi. Selain itu, meskipun implikasi dari penerapan media sosial oleh organisasi tidak dipahami dengan baik. Mereka mendukung peneliti untuk mempelajari cara-cara media sosial dalam memberikan dampak bagi praktik-praktik sosial yang terjadi dalam organisasi.

Penelitian sebelumnya telah memberikan wawasan tentang peran penting social media dalam berbagai aspek. Namun, riset terkait dengan adopsi social media di universitas masih belum banyak diulas (Vrontis, El Nemar, Ouwaida, \& Shams, 2018b), terutama dampak adopsi tersebut terhadap penerimaan mahasiswa dan dukungan terhadap popularitas institusi pendidikan tinggi di dunia maya. Penelitian sebelumnya banyak memfokuskan pada hubungan social media pada sector privat dan organisasi berorientasi profit. Padahal, saat ini adopsi social media telah menyentuh semua kalangan termasuk organisasi pendidikan tinggi. Bertujuan untuk mengatasi kesenjangan ini, maka kami ingin menguji dampak adopsi media social oleh universitas terhadap penerimaan mahasiswa serta popularitas institusi pendidikan tinggi di dunia maya.

Sosial media berperan penting dalam memberikan perubahan cara menjalankan bisnis pada berbagai jenis industri akhir-akhir ini, termasuk pendidikan tinggi (Vrontis et al., 2018b). Sosial media menyediakan metode baru untuk menjangkau orang-orang dapat terhubung satu sama lain. Media sosial mampu mempengaruhi berbagai aspek perilaku individu termasuk kesadaran, pendapat, dan sikap (Assimakopoulos, Antoniadis, Kayas, \& Dvizac, 2017). Pendidikan tinggi dapat mengadopsi teknologi baru untuk memudahkan komunikasi dengan pihak eksternal maupun internal, termasuk penggunaan media social (Ann Voss \& Kumar, 2013a). Sebagai salah satu produk teknologi, media social seperti Facebook, twitter, Instagram, YouTube, dan lainnya memiliki fitur yang salah satu fungsi utamanya adalah sebagai alat 
komunikasi. Mangold \& Faulds, (2009), menyatakan bahwa bersosialisasi melalui internet telah menjadi pilihan yang relevan dalam berkomunikasi. Sosial media ini berguna untuk mengungkapkan bagaimana setiap orang terhubung satu sama lain yang memiliki kepentingan (Ginevra \& Monica, 2017).

Adopsi media sosial memiliki efek signifikan pada institusi pendidikan tinggi. Perkembangan perangkat lunak dan teknologi memiliki kekuatan dalam memberikan cara baru dalam sistem pendidikan tinggi. Lembaga dan individu mulai menggunakan pendekatan baru dalam penggunaan media sosial untuk berbagai fungsi di institusi pendidikan tinggi. Beberapa institusi pendidikan tinggi telah menciptakan jaringan sosial tertutup untuk fakultas, staf, dan mahasiswa untuk menghubungkan berbagai segmen di lembaganya dan menciptakan komunitas online pada institusi mereka. Institusi pendidikan tinggi lainnya membuat jaringan online di dalam kelas, pendidikan tinggi, dan lintas kampus. Jaringan-jaringan tersebut dilengkapi dengan alat kolaborasi online untuk memudahkan interaksi dengan beberapa individu dan unit di lembaga pendidikan tinggi.

Teori pemrosesan informasi sosial menekankan makna sosial dan menunjukkan pentingnya lingkungan sosial sebagai sumber informasi dan isyarat untuk persepsi dan perilaku individu. Teori ini memberikan wawasan untuk menguji kekuatan dampak interpersonal di media sosial (Guo, 2012). Media computer memungkinkan individu dan semua orang dapat berkomunikasi dengan lainnya tanpa adanya kontak tatap muka satu sama lain. Media social mampu menyampaikan informasi yang kaya pada sebagian besar individu yang terjebak pada ruang dan waktu. Media social online memungkinkan pengguna dapat memengaruhi individu yang lain secara lebih efektif dan relevan.

Terlepas dari peran vital media social, institusi pendidikan tinggi memiliki kewajiban untuk ikut berperan dalam menciptakan masyarakat yang berpengetahuan dan berkontribusi positif terhadap individu, masyarakat, dan lingkungan (Ansari, 2019). Sejalan dengan fungsi tersebut, media sosial dapat menjadi pilihan bagi institusi pendidikan tinggi sebagai alat komunikasi dalam menyampaikan tanggungjawab universitas (Fosso Wamba, Edwards, \& Akter, 2017; Seigler, 2015; Vrontis, El Nemar et al., 2018c). Adopsi sosial media oleh pendidikan tinggi akan membantu mereka dalam membangun kesadaran masyarakat, mahasiswa, dan mempertahankan jumlah mahasiswa (Rutter, Roper, \& Lettice, 2016). Adopsi social media yang dikelola oleh institusi pendidikan tinggi akan memberikan dampak pada pengembangan institusi tersebut dengan lebih berkelanjutan (Rylander, Jacobsen, \& Roos, 2000a). Dalam banyak literature disebutkan bahwa adopsi social media dapat 
dijadikan sebagai brand strategy (Bochenek \& Blili, 2013), strategi inovasi (Cao et al., 2018; Mention, Barlatier, \& Josserand, 2019), dan strategi dalam merekrut mahasiswa (Assimakopoulos et al., 2017) oleh pendidikan tinggi.

Adopsi media social telah terbukti menjadi alat yang efektif bagi institusi pendidikan tinggi untuk menerapkan strategi branding yang beragam, mengingat bahwa media social tersebut memungkinkan mahasiswa untuk berbagi pengalaman dan opini tentang kualitas pendidikan tinggi secara real time (McCoy, Nelson, \& Weigle, 2018). Banyak institusi pendidikan tinggi telah cepat mengadopsi layanan jejaring sosial seperti Facebook, Instagram dan Twitter, sebagai sebuah langkah untuk mengubah cara manajemen berhubungan dengan pihak eksternal kampus dan memungkinkan kolaborasi dengan mereka. Interaksi media sosial di dunia pendidikan tinggi tidak transactional dalam arti tradisional, mereka menyediakan cara bagi lembaga untuk terus terlibat dengan stakeholder mereka. Bentuk lain dari keterlibatan, yang dipilih adalah komitmen afektif sebagai sebuah ikatan sukarela antara entitas.

Penelitian ini dilakukan pada seluruh universitas di Provinsi Jawa Timur. Pemilihan lokasi penelitian atas dasar bahwa di provinsi Jawa Timur terdapat universitas dengan jumlah terbesar dibandingkan tempat lainnya. Mereka memiliki keunikan, semua lembaga pendidikan tinggi / universitas memiliki departemen yang berbeda. Sebagai contoh, departemen ekonomi dan bisnis biasanya dibagi menjadi dua departemen atau lebih (Rahmani et al., 2014). Setiap departemen memiliki kontribusi untuk mencapai kemajuan universitas. Social media yang menjadi variabel utama penelitian ini digunakan untuk melihat dampaknya terhadap recruitment mahasiswa, dan popularitas suatu universitas. Kami mengukur tingkat recruitment mahasiswa berdasarkan data jumlah mahasiswa dari kementerian Riset Teknologi, dan Pendidikan Tinggi. Sementara untuk popularitas institusi pendidikan tinggi, kami mengukurnya menggunakan data jumlah akses tahunan pada website universitas. Data tersebut diperoleh dengan melakukan akses pada http://www.statshow.com.

Penelitian ini menggunakan data seluruh pendidikan tinggi di Provinsi Jawa Timur. Berdasarkan data dari kementerian Riset, Teknologi, dan Pendidikan Tinggi, terdapat sejumlah 329 pendidikan tinggi swasta dan 10 pendidikan tinggi negeri di Jawa Timur. Banyaknya jumlah pendidikan tinggi menyebabkan persaingan dalam memperoleh mahasiswa sangat ketat. Hal ini dialami oleh hampir seluruh pendidikan tinggi negeri maupun swasta. Kami akan menguji adopsi social media seperti Facebook, Instagram, twitter, dan channel YouTube oleh pendidikan tinggi dan dampaknya terhadap jumlah penerimaan mahasiswa, dan popularitas pendidikan tinggi. Kami melakukan identifikasi terhadap jumlah postingan, viewer, follower, subscriber pada masing-masing media social yang digunakan oleh pendidikan tinggi, untuk menjamin kualitas data, proses tersebut kami lakukan pada waktu yang sama untuk menghindari adanya perubahan pada jumlah postingan, viewer, follower, maupun subscriber. Selanjutnya, kami melakukan analisis regresi untuk melihat dampak adopsi media social pada institusi pendidikan tinggi tersebut. 
Adopsi sosial media oleh institusi pendidikan tinggi sebelumnya telah menunjukkan perannya dalam perekrutan mahasiswa. Penelitian ini menemukan bahwa, adopsi media sosial oleh institusi pendidikan tinggi mampu memberikan pengaruh pada kinerja institusi atau jumlah mahasiswa. Di samping itu, penggunaan media sosial Facebook, Instagram, dan tweeter dapat meningkatkan popularitas institusi pendidikan tinggi di dunia maya. Jumlah visitor tahunan pada website resmi pendidikan tinggi meningkat sejalan dengan meningkatnya jumlah postingan, viewer, dan follower pada akun sosial media yang dikelolanya.

Hasil penelitian mengindikasikan peran vital media social sebagai alat komunikasi yang efektif dan efisien dalam menunjang kinerja pendidikan tinggi. Dalam sudut pandang manajemen strategis, pendidikan tinggi dapat menggunakan media social sebagai sebuah strategi. Strategi ini meliputi strategi dalam recruitment mahasiswa, strategi komunikasi dengan alumni, masyarakat, maupun dengan stakeholder lainnya. Tingginya pengguna media social dapat menjadi peluang untuk menginformasikan kinerja yang dicapai oleh pendidikan tinggi kepada pihak eksternal. Disisi lain, penelitian ini mampu memberikan kontribusi teoretis yang cukup signifikan bagi para peneliti di bidang terkait yang menarik. Kami juga menyarankan agar peneliti selanjutnya dapat memperluas kajian penggunaan media social untuk institusi nonprofit lainnya. Selain itu dapat juga melakukan komparasi penggunaan media social antar Negara dengan kebudayaan yang berbeda.

Sisa dari artikel ini mencakup kajian literatur yang komprehensif meliputi kajian tentang peran penting media social dalam merekrut mahasiswa, kinerja manajemen, dan popularitas di internet. Kami juga memberikan gambaran tentang sistem pendidikan tinggi di Indonesia, yang meliputi pencapaian kinerja pendidikan tinggi, adopsi media social, serta pola recruitment mahasiswa. Bagian berikutnya meliputi metodologi penelitian dan menjelaskan metode pengumpulan data dan analisis data penelitian. Berikutnya, kami membahas hasil dan temuan penelitian tentang dampak adopsi media social bagi pendidikan tinggi. Bagian terakhir simpulan, implikasi dan rekomendasi penelitian selanjutnya.

\section{METODE PENELITIAN}

\section{Desain Penelitian}

Pendekatan yang digunakan dalam penelitian ini adalah pendekatan kausalitas untuk menguji pengaruh atau hubungan dua variabel atau lebih. Dalam hal ini kami menguji dampak adopsi media sosial bagi institusi pendidikan tinggi. Untuk menjelaskan hubungan antara kegunaan adopsi social media oleh pendidikan tinggi,

6 Jurnal Serambi Ilmu. p-ISSN 1693-4849, e-ISSN 2549-2306 Journal of Scientific Information and Educational Creativity 
kita perlu untuk mengidentifikasi penggunaan social media oleh pendidikan tinggi. Untuk tujuan ini, kami harus melakukan identifikasi pada pendidikan tinggi target terkait dengan jenis-jenis media social yang digunakan. Kemudian, melakukan analisis masing-masing peran media social terhadap kinerja institusi dan popularitas pendidikan tinggi di dunia maya. Penelitian ini menggunakan data sekunder berupa data jumlah mahasiswa yang kami peroleh dari Kementerian Riset, teknologi, dan pendidikan Tinggi. Serta data jumlah akses tahunan pada website resmi universitas yang kami dapatkan dari www.statshow.com. Sementara itu untuk data jumlah follower, subscriber, postingan, dan viewer dari social media kami dapatkan dengan cara mengakses satu persatu media social yang dikelola oleh pendidikan tinggi. Untuk memastikan akurasi data yang kami peroleh, maka kami mengaksesnya pada hari yang sama.

\section{Sampel dan Sumber Data}

Kami menggunakan seluruh universitas di Provinsi jawa Timur - Indonesia sebagai sample penelitian. Alasan pemilihan Jawa Timur sebagai sample karena di daerah ini merupakan tempat keberadaan pendidikan tinggi terbanyak di Indonesia. Di dalamnya terdapat 329 pendidikan tinggi swasta dan 10 pendidikan tinggi negeri. Kami selanjutnya mengeluarkan pendidikan tinggi yang memiliki data tidak lengkap.

Tabel 1. Sample penelitian

\begin{tabular}{|c|c|}
\hline Keterangan & Jumlah \\
\hline Jumlah Pendidikan Tinggi & 339 \\
\hline Data tidak lengkap & 30 \\
\hline Sampel Akhir & 309 \\
\hline
\end{tabular}

Studi ini bertujuan untuk menguji dampak adopsi media social terhadap kinerja dan popularitas institusi pendidikan tinggi di Indonesia. Sosial media yang kami jadikan variabel independen adalah media social yang banyak digunakan oleh pendidikan tinggi sebagai sarana komunikasi visual kepada pihak eksternal kampus seperti Facebook, Instagram, Twitter, dan saluran You Tube. Kami melakukan pengamatan terhadap jumlah viewer (faceview) dan follower Facebook (Facefollow), jumlah postingan (Inspost) dan follower Instagram (Insfollow), jumlah tweet (Tweetpost) dan follower twitter (Tweetfollow), serta jumlah subscriber (YTSubs) dan viewer (YTView) di channel resmi YouTube masing-masing institusi pendidikan tinggi (Dumays \& Guthrie, 2017; Lardo, Dumay, Trequattrini, \& Russo, 2017). Sementara itu, untuk variabel kinerja institusi pendidikan tinggi kami menggunakan jumlah mahasiswa (Studt) sebagai indicator kinerja (Fujita, Harrigan, \& Soutar, 2017; Lau, 2017; Rutter et al., 2016). Selanjutnya, popularitas institusi pendidikan tinggi di website, kami mengukurnya menggunakan data jumlah pengunjung website (Webview) pendidikan tinggi yang kami peroleh dengan mengakses www.statshow.com. Kami menggunakan data pengunjung website tahunan untuk mengukur variabel ini (McCoy et al., 2018). 


\section{Analisis Data}

Untuk menguji hipotesis, kami menggunakan IBM SPSS Statistics sebagai program utama analisis statistik. Kami melakukan analisis deskriptif pada semua variabel yang digunakan dalam penelitian ini untuk melihat mean, nilai maksimum, minimum, dan standar deviasi pada masing-masing variabel. Selanjutnya, kami melakukan analisis korelasi untuk melihat hubungan masing-masing variabel. Setelah itu kami melakukan analisis regresi untuk menunjukkan pengaruh adopsi media social terhadap variabel kinerja institusi pendidikan tinggi yang diproksikan dengan jumlah mahasiswa dan popularitas nya di dunia maya yang diproksikan dengan jumlah akses tahunan pada masing-masing website pendidikan tinggi. Kami memastikan data tersebut telah terbebas dari masalah multikolinieritas.

\section{HASIL PENELITIAN DAN PEMBAHASAN}

Bagian ini menjelaskan hasil analisis data penelitian serta pembahasan tentang dampak adopsi media sosial oleh pendidikan tinggi. Pertama, menjelaskan output statistik terhadap data yang dikumpulkan, hasil analisis, serta diskusi tentang dampak adopsi sosial bagi institusi pendidikan tinggi.

Tabel 2. Deskriptif Statistik

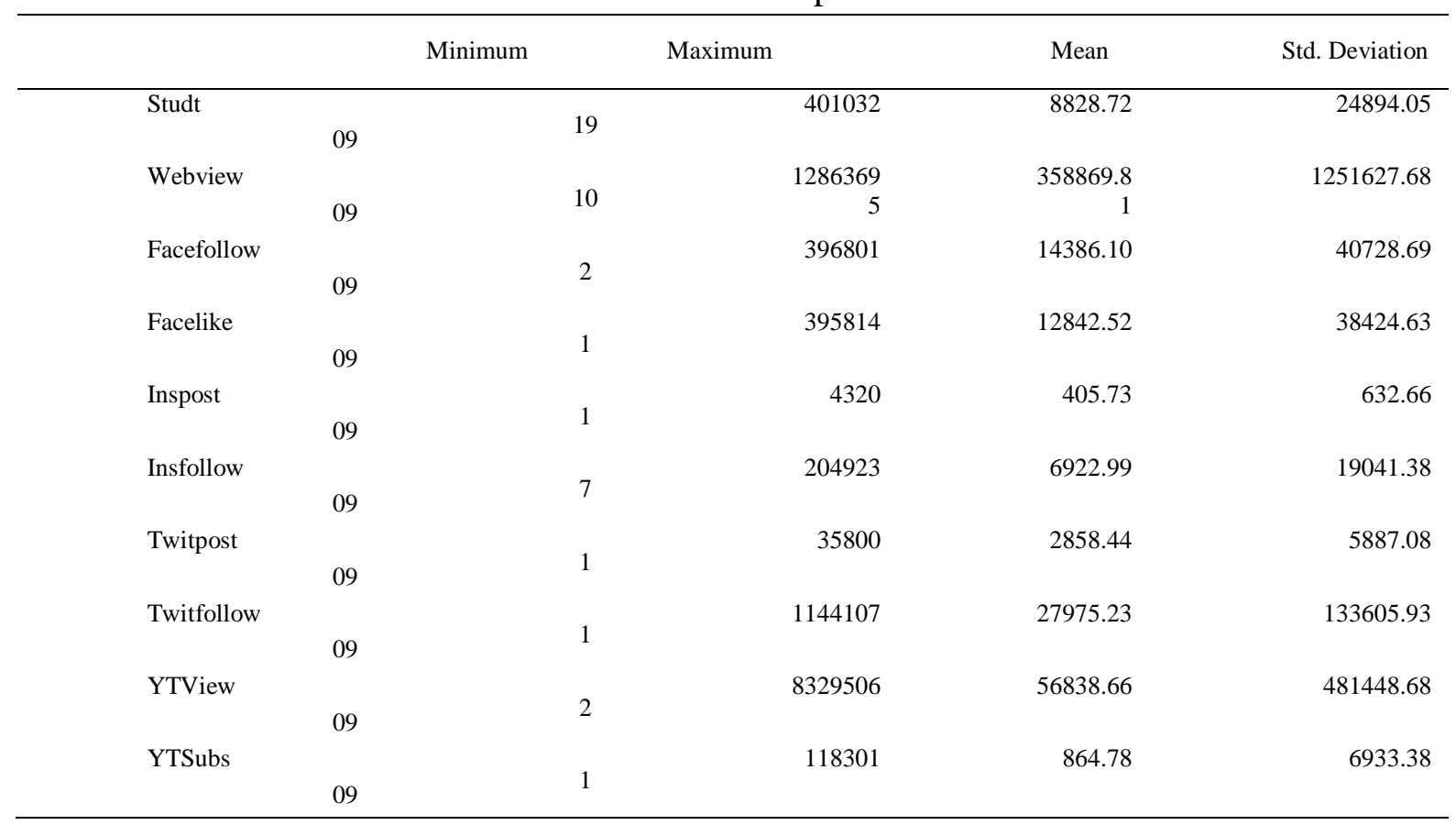

8 Jurnal Serambi Ilmu. p-ISSN 1693-4849, e-ISSN 2549-2306 Journal of Scientific Information and Educational Creativity 
Tabel II menyajikan ringkasan statistik deskriptif dari dependen dan independen variabel yang digunakan dalam penelitian ini. Data sample kami menunjukkan bahwa rata-rata jumlah mahasiswa (Studt) sebesar 8828.72; jumlah akses tahunan (Webview) sebesar 358869.81; Jumlah pengikut Facebook dan jumlah like masing-masing memiliki rata-rata 14386.10 dan 12842.52; Jumlah pengikut follower dan postingan memiliki rata-rata 6922.99 dan 405.73; Follower Tweeter dan postingan dengan rata-rata 27975.23 dan 2858.44 ; serta jumlah subscriber dan viewer memiliki jumlah rata-rata 864.78 dan 56838.66. Tabel II juga melaporkan bahwa media social tweeter memiliki nilai rata-rata paling besar 27975.23 disusul oleh Facebook ditempat kedua 14386.10 dibandingkan dengan situs media lainnya seperti Instagram dan saluran You Tube. Hal ini menunjukkan bahwa sesorang lebih tertarik mengakses tweeter dan lama Facebook resmi pendidikan tinggi dibandingkan dengan lainnya. Hal yang menarik adalah variabel Viewer YouTube (YTView) memiliki nilai rata-rata yang paling besar. Hal ini menunjukkan bahwa sesorang tertarik menonton video yang diunggah oleh pendidikan tinggi meskipun mereka tidak melakukan subscriber pada channel You Tube pendidikan tinggi. Ketika mereka tertarik pada salah satu institusi pendidikan tinggi, maka mereka juga melakukan akses terhadap channel resmi di YouTube meskipun tidak melakukan subscribe.

Tabel III menunjukkan analisis korelasi atas semua variabel yang digunakan dalam studi ini. Nilai korelasi memberikan beberapa dukungan awal dalam pembuktian $\mathrm{H} 1$ dan $\mathrm{H} 2$, dimana variabel memiliki korelasi yang signifikan dengan variabel jumlah mahasiswa (Studt) popularitas (Webview), misalnya Facefollow, facelike, inspost, dan insfollow memiliki korelasi yang signifikan. Penelitian ini tidak menemukan masalah multikolinieritas dengan nilai VIF dari semua variabel berkisar antara 1,094 dan 8,735. Selain itu seperti tampak pada tabel III, bahwa korelasi berpasangan variabel umumnya tidak muncul yang mengindikasikan kekhawatiran terjadinya masalah multikolinieritas dalam memperkirakan regresi.

Tabel 3. Analisis Korelasi

\begin{tabular}{|c|c|c|c|c|c|c|c|c|c|c|}
\hline & 1. & & & & & & & & & \\
\hline tuad & 2 & & & & & & & & & \\
\hline ebview & & $307 * *$ & & & & & & & & \\
\hline acefollow & $\begin{array}{l}3 . \\
4 .\end{array}$ & $396^{* *}$ & $597 * *$ & & & & & & & \\
\hline acelike & 5 & $406 * *$ & $641^{* *}$ & $937^{* *}$ & & & & & & \\
\hline nspost & J. & $141^{*}$ & $128^{*}$ & $293 * *$ & $270^{* *}$ & & & & & \\
\hline nsfollow & 6. & $316^{* * *}$ & $796^{* *}$ & $650^{* * *}$ & $646^{* * *}$ & $295^{* *}$ & & & & \\
\hline weetpost & 8. & $291 * *$ & $323^{* *}$ & $333^{* *}$ & $356^{* * *}$ & $345^{* *}$ & $418^{* *}$ & & & \\
\hline weetfollov & $N^{N} 9$. & $418^{* *}$ & $550 * *$ & $621 * *$ & $660^{* *}$ & .09415 & $662^{* * *}$ & $398 * *$ & & \\
\hline TView & 10. & .08087. & $184 * *$ & $277 * *$ & $288^{* * *}$ & .03338 & $297 * *$ & $132 *$ & $451^{* * *}$ & \\
\hline TSubs & & .0677 & .0723 & $130 *$ & .07613 & .03754 & $184 * *$ & $182 * *$ & .082 & .098 \\
\hline
\end{tabular}


**. Correlation is significant at the 0.01 level (2-tailed).

*. Correlation is significant at the 0.05 level (2-tailed).

\section{Analisis Regresi}

Tabel 4 menunjukkan hasil regresi kuadrat terkecil yang biasa digunakan dalam pengujian hubungan antar variabel. Di sini, kami merangkum hasil analisis dampak adopsi media social terhadap kinerja dan popularitas institusi pendidikan tinggi. Seperti ditunjukkan dalam tabel ini, hasil menunjukkan hubungan positif dan signifikan antara Tweetpost dan Tweetfollow terhadap kinerja institusi pendidikan tinggi, kami menemukan adanya hubungan negative dan signifikan antara YTView kinerja institusi pendidikan tinggi. Kami tidak menemukan adanya pengaruh penggunaan Facebook dan Instagram pada kinerja pendidikan tinggi. Untuk popularitas pendidikan tinggi di dunia maya, kami menemukan adanya hubungan yang signifikan antara adopsi media social Facebook, Instagram, dan YouTube. Kami tidak menemukan penggunaan tweeter oleh pendidikan tinggi berdampak pada popularitas institusi di dunia maya.

Tabel 4. Hasil Regresi

\begin{tabular}{|c|c|c|c|c|}
\hline \multirow{2}{*}{$\begin{array}{c}\text { Variabel Dependen } \\
\mathrm{N}\end{array}$} & \multicolumn{2}{|c|}{ Student } & \multicolumn{2}{|c|}{ Webview } \\
\hline & & 309 & & 309 \\
\hline Adjusted R2 & & 0.21 & & 0.69 \\
\hline F statistik & & 11.53 & & 86.58 \\
\hline Prob. & & $.000 \mathrm{~b}$ & & $.000 \mathrm{~b}$ \\
\hline Intercept & 4231.90 & & 66934.66 & \\
\hline Independen Variabel & Beta & Value $^{p}$ & Beta & $p$ Value \\
\hline Facefollow & 0.084 & 0.361 & 6.803 & 0.019 \\
\hline Facelike & 0.062 & 0.528 & 15.419 & 0.000 \\
\hline Inspost & 1.176 & 0.601 & 302.152 & 0.000 \\
\hline Insfollow & -0.096 & 0.339 & 49.854 & 0.000 \\
\hline Tweetpost & 0.490 & 0.054 & 3.665 & 0.648 \\
\hline Tweetfollow & 0.061 & 0.000 & -0.781 & 0.106 \\
\hline YTView & -0.007 & 0.025 & -0.181 & 0.052 \\
\hline YTSubs & 0.070 & 0.711 & -10.498 & 0.081 \\
\hline
\end{tabular}

\section{Adopsi Sosial Media dan Kinerja Institusi Pendidikan Tinggi}


Pendidikan tinggi merupakan organisasi di mana interaksi sosial di dalamnya sangatlah kuat, Hal ini mengarah pada jenis yang spesifik tentang budaya organisasi. Kemajuan dan perkembangan institusi pendidikan tinggi sangat tergantung pada keberhasilan mereka dalam melakukan inovasi secara berkelanjutan (Rylander et al., 2000b). Kapasitas tersebut adalah inti dari strategi suatu pendidikan tinggi. Di lain pihak, pendidikan tinggi memiliki peran penting dalam mendukung perkembangan masyarakat kontemporer karena mereka memiliki tanggung jawab khusus untuk memproduksi dan menyebarkan ilmu pengetahuan serta upaya pengembangan penelitian dan sumber daya manusia. Hasil penelitian, kemampuan transmisi, dan kualitas serta jumlah mahasiswa adalah komponen penting yang menentukan kinerja mereka (Ann Voss \& Kumar, 2013b; Eom et al., 2018; Linke \& Zerfass, 2013).

Tabel IV menunjukkan dampak adopsi media social terhadap jumlah mahasiswa. Penggunaan media Facebook dan Instagram oleh universitas ternyata tidak memiliki dampak terhadap kinerja pendidikan tinggi di Indonesia. Ada beberapa hal yang menjadikan media social Facebook dan Instagram tidak memiliki dampak dalam menunjang kinerja pendidikan tinggi misalnya banyak universitas tampaknya tidak fokus dalam mengelola Facebook dan Instagram mereka untuk upaya pada satu individu yang berbeda, melainkan menampilkan konten acak dan terkesan tidak fokus dalam melakukan postingan pada media social mereka (Ann Voss \& Kumar, 2013b). Kadang-kadang kurangnya fokus dapat menghasilkan konten yang kurang menarik dan menciptakan kebingungan. Akan lebih baik bagi suatu organisasi untuk memiliki rencana konkret dan memfokuskan upaya mereka pada satu target audient sampai tujuan tercapai, daripada mencoba untuk menampilkan postingan yang tidak berbobot dan tidak jelas sasarannya (Silva, Tavares, Silva, \& Lameiras, 2019).

Berbeda dengan Facebook dan Instagram, media social tweeter dan YouTube memberikan pengaruh pada jumlah mahasiswa. Jumlah postingan dan follower pada situs resmi tweeter institusi pendidikan tinggi menjadi perhatian dan pertimbangan bagi seseorang untuk menentukan studi di masa depan (Alsufyan \& Aloud, 2017; Vrontis et al., 2018a). Jumlah postingan pada tweeter yang dikelola oleh pendidikan tinggi dan followernya memiliki dampak signifikan dalam menunjang kinerja institusi pendidikan tinggi. Semua kelebihan yang diberikan oleh platform ini seperti kemudahan dalam navigasi, login, keterukuran, dan efektifitas menjadi salah satu alasan mengapa media social ini sangat efektif digunakan sebagai alat komunikasi oleh institusi pendidikan tinggi. Mudah dinavigasi dan memperbarui, "link to" dan mempromosikan apapun.

Sejak awal kemunculan internet dan integrasi email telah mengubah cara komunikasi setiap individu. Hal ini diperkuat dengan keberadaan social media yang mempengaruhi hamper di setiap lini kehidupan. Social media menciptakan konektivitas antar individu, masyarakat, lembaga, dan institusi. Dalam masyarakat saat ini, membangun jejaring sosial elektronik lebih penting daripada sebelumnya untuk mengelola perubahan di lingkungan pendidikan tinggi dan masyarakat sekitarnya, berkorelasi dengan harapan ekonomi saat ini. Perubahan cara komunikasi untuk 
sebuah pendidikan tinggi dimulai dengan memahami lanskap pendidikan tinggi dan semua lingkaran dalamnya. Ini juga dimulai dengan rencana strategis pendidikan tinggi dengan misi dan pernyataan nilai yang memahami di mana dan bagaimana media sosial cocok dengan rencana ini.

Pentingnya penelitian ini adalah untuk memperluas penelitian sebelumnya tentang penggunaan media sosial di pendidikan tinggi dan universitas. Media sosial memberi kesempatan untuk mengintegrasikan institusi pendidikan tinggi dengan pihak eksternal yang dapat menciptakan keselarasan mencapai keberlanjutan. Pendidikan tinggi perlu untuk mengelola media social dengan maksimal untuk mempermudah komunikasi dengan pihak alumni, masyarakat, dan mahasiswa.

\section{Adopsi Sosial Media dan Popularitas Institusi Pendidikan Tinggi}

Pendidikan tinggi dan lembaga akademis lainnya melihat kehadiran dan visibilitas mereka di Web sebagai pusat pencapaian reputasi. Dalam konteks ini, kinerja pendidikan tinggi dapat direfleksikan melalui konten informasi yang disampaikan pendidikan tinggi di Web baik berupa kinerja akademik maupun organisasi secara keseluruhan (Aguillo et al., 2008). Peringkat suatu pendidikan tinggi dapat berperan penting dalam meningkatkan reputasi institusi. Sehingga, dapat meningkatkan nilai web yang dikelola oleh pendidikan tinggi tersebut.

Visibilitas institusi pendidikan tinggi semakin menjadi perhatian akhir-akhir ini. Semua informasi yang disajikan oleh pendidikan tinggi di Web akademik dilihat sebagai refleksi dari kinerja universitas. Keberadaan media sosial seperti Facebook, Instagram, dan Twitter yang semakin terintegrasi diyakini akan menggiring sesorang untuk mengetahui kondisi pendidikan tinggi melalui web yang dikelola dimana di dalamnya menyajikan informasi lebih lengkap dari pada situs media social.

Hasil penelitian menujukkan bahwa adopsi media social oleh pendidikan tinggi akan berpengaruh terhadap visibilitas web nya. Penggunaan media social Facebook, Instagram, tweeter, dan YouTube akan berpengaruh pada popularitas institusi pendidikan tinggi di dunia maya. Kami berpendapat, penggunaan media social akan menggiring sesorang untuk lebih jauh mengakses website resmi pendidikan tinggi untuk memenuhi kebutuhan informasinya. Seseorang akan mengakses web pendidikan tinggi sehingga hal ini akan meningkatkan nilai website dan popularitas nya.

Dalam era sekarang ini, pencarian informasi telah bergeser dari paper information menjadi informasi berbasis web. Kecepatan informasi melaui web menjadi alasan bagi sesorang untuk lebih tertarik memperoleh informasi melalui web. Dalam konteks pendidikan tinggi, website telah menjadi bagian penting bagi mereka 
dalam memberikan informasi akademik maupun non-akademik. Kinerja akademik suatu pendidikan tinggi dapat diketahui melalui informasi yang disajikan pada masingmasing website resmi pendidikan tinggi. Visibilitas website pendidikan tinggi juga ditopang oleh adopsi media social yang secara nyata telah berdampak pada popularitas di dunia maya.

\section{KESIMPULAN}

Mempelajari media sosial dan adopsi nya di lingkungan pendidikan tinggi memberikan peluang besar untuk penelitian dan pengembangan. Dengan memahami manfaat penggunaan media sosial, pendidikan tinggi dapat meningkatkan komunikasi dan hubungan dengan mahasiswa dan stakeholder lainnya. Untuk itu, Institusi pendidikan tinggi perlu memposting kegiatan-kegiatan mahasiswa, kegiatan akademik, dan acara kampus secara teratur untuk memberikan informasi kepada pihak luar terkait dengan perkembangan kampus. Karena jenis postingan seperti ini paling tidak akan mendapat respons suka, berbagi, dan komentar dari pihak luar dan memainkan peran penting dalam mendukung kinerja pendidikan tinggi dan penerimaan mahasiswa.

Penelitian ini mengeksplorasi pengaruh adopsi media sosial di lingkungan pendidikan tinggi terhadap kinerja dan popularitas pendidikan tinggi di dunia maya. Penelitian ini berusaha memahami bagaimana peran media sosial yang dikelola di lingkungan pendidikan tinggi dalam menunjang kinerja penerimaan mahasiswa. Kami juga menguji peran social media terhadap popularitas pendidikan tinggi di dunia maya dengan melihat jumlah visitor pada masing-masing situs Web yang dikelola oleh pendidikan tinggi. Hasil penelitian menunjukkan bahwa adopsi sosial media seperti Facebook dan Instagram tidak berdampak pada jumlah mahasiswa, namun penggunaan tweeter dan YouTube memberikan dampak signifikan bagi jumlah mahasiswa di Institusi pendidikan tinggi. Kami juga menemukan bahwa adopsi media sosial oleh pendidikan tinggi akan berdampak pada meningkatnya jumlah visitor pada website resmi institusi pendidikan tinggi.

Berdasarkan studi penelitian sebelumnya dan hasil penelitian ini, ada beberapa rekomendasi yang dapat dibuat untuk pimpinan universitas sehubungan dengan bagaimana penggunaan situs media sosial mempengaruhi kinerja penerimaan mahasiswa dan popularitas pendidikan tinggi. Universitas perlu terus menggunakan akun media sosial mereka untuk tujuan memberikan informasi bagi pihak eksternal kampus; namun, universitas perlu melakukan pengelolaan pada akun media sosialnya dan mengenali siapa target yang dituju pada setiap postingannya. Pihak kampus harusnya menyediakan lembaga khusus yang bertugas untuk mengelola semua konten yang akan dimuat pada akun media sosial yang dimilikinya. Selain itu channel YouTube universitas harus terus diperbarui dengan konten video baru juga untuk memenuhi kebutuhan calon mahasiswa mereka, dan sebagai hasilnya, meningkatkan jumlah penayangan dan subscriber.

Studi selanjutnya kami sarankan untuk melakukan studi kasus pada pendidikan tinggi tentang dampak adopsi sosial media pada perekrutan organisasi, strategy 
organisasi, branding, dan penggunaan media sosial dikalangan mahasiswa. Hal ini penting dilakukan untuk mengungkap makna sebenarnya dari manfaat yang diberikan oleh sosial media bagi institusi pendidikan tinggi.

\section{DAFTAR PUSTAKA}

Ahmed, Y. A., Ahmad, M. N., Ahmad, N., \& Zakaria, N. H. (2019). Social media for knowledge-sharing: A systematic literature review. Telematics and Informatics, 37(January 2018), 72-112.

Akmese, H., Aras, S., \& Akmese, K. (2016). Financial Performance and Social Media: A Research on Tourism Enterprises Quoted in Istanbul Stock Exchange (BIST). Procedia Economics and Finance, 39(November 2015), 705-710.

Alalwan, A. A. (2018). Investigating the impact of social media advertising features on customer purchase intention. International Journal of Information Management, 42(June), 65-77.

Alsufyan, N. K., \& Aloud, M. (2017). The state of social media engagement in Saudi universities. Journal of Applied Research in Higher Education, 9(2), 267-303.

Ann Voss, K., \& Kumar, A. (2013a). The value of social media: are universities successfully engaging their audience? Journal of Applied Research in Higher Education, 5(2), 156-172.

Ann Voss, K., \& Kumar, A. (2013b). The value of social media: are universities successfully engaging their audience? Journal of Applied Research in Higher Education, 5(2), 156-172.

Ansari, B. I., \& Burhanuddin, A. G. (2019). Pengembangan Kinerja Pendidikan Tinggi Melalui Manajemen Berbasis Institusi (Studi Kasus pada Pendidikan Tinggi Swasta di Lingkungan LLDikti 13 Aceh). JURNAL SERAMBI ILMU, 20(2), 174-188.

Assimakopoulos, C., Antoniadis, I., Kayas, O. G., \& Dvizac, D. (2017). Effective social media marketing strategy: Facebook as an opportunity for universities. International Journal of Retail and Distribution Management, 45(5), 532-549.

Bochenek, L. M., \& Blili, S. (2013). Social media champions - Drivers and sophistication process of social media strategic management. Advanced Series in Management, 11, 143-167.

Cao, Y., Ajjan, H., Hong, P., \& Le, T. (2018). Using social media for competitive business outcomes: An empirical study of companies in China. Journal of Advances in Management Research, 15(2), 211-235.

Chen, Y. C., Hung, M., \& Wang, Y. (2018). The effect of mandatory CSR disclosure 
on firm profitability and social externalities: Evidence from China. Journal of Accounting and Economics, 65(1), 169-190.

Corcoran, N., \& Duane, A. (2017). Using enterprise social networks as a knowledge management tool in higher education. VINE Journal of Information and Knowledge Management Systems, 47(4), 555-570.

Corral de Zubielqui, G., Fryges, H., \& Jones, J. (2019). Social media, open innovation \& HRM: Implications for performance. Technological Forecasting and Social Change, 144(March 2016), 334-347.

Dumay, J., \& Guthrie, J. (2017). Involuntary disclosure of intellectual capital: is it relevant? Journal of Intellectual Capital, 18(1), 29-44.

Eom, S. J., Hwang, H., \& Kim, J. H. (2018). Can social media increase government responsiveness? A case study of Seoul, Korea. Government Information Quarterly, 35(1), 109-122.

Figueira, Á. (2018). Uncovering social media content strategies for worldwide topranked universities. Procedia Computer Science, 138, 663-670.

Fosso Wamba, S., Edwards, A., \& Akter, S. (2017). Social media adoption and use for improved emergency services operations: the case of the NSW SES. Annals of Operations Research, 1-21.

Fujita, M., Harrigan, P., Roy, S. K., \& Soutar, G. (2019). Two-way acculturation in social media: The role of institutional efforts. Technological Forecasting and Social Change, 145(December 2017), 532-542.

Fujita, M., Harrigan, P., \& Soutar, G. N. (2017). International students' engagement in their university's social media: An exploratory study. International Journal of Educational Management, 31(7), 1119-1134.

Gálvez-Rodríguez, M. del M., Caba-Pérez, C., \& López-Godoy, M. (2016). Drivers of Twitter as a strategic communication tool for non-profit organizations. Internet Research, 26(5), 1052-1071.

Ginevra, G., \& Monica, F. (2017). New Forms of Communication Summary. In The Influence of Post-Biblical Hebrew and Aramaic on the Translator of Septuagint Isaiah (pp. 1-38). Emerald Group Publishing Ltd.

Grimaldi, D., \& Fernandez, V. (2019). Performance of an internet of things project in the public sector: The case of Nice smart city. Journal of High Technology Management Research, 30(1), 27-39.

Guo, M. (2012). Marketing and Branding in Online Social Media Environments : Examining Social Media Adoption by the Top 100 Global Brands. Books.Google.Com, 161-180.

Hamid, S., Ijab, M. T., Sulaiman, H., Md. Anwar, R., \& Norman, A. A. (2017, May 2). Social media for environmental sustainability awareness in higher education. International Journal of Sustainability in Higher Education.

Karakiza, M. (2015). The Impact of Social Media in the Public Sector. Procedia Social and Behavioral Sciences, 175, 384-392.

Lardo, A., Dumay, J., Trequattrini, R., \& Russo, G. (2017). Social media networks as 
drivers for intellectual capital disclosure: Evidence from professional football clubs. Journal of Intellectual Capital, 18(1), 63-80.

Lau, W. W. F. (2017). Effects of social media usage and social media multitasking on the academic performance of university students. Computers in Human Behavior, 68, 286-291.

Lenartz, A. J. (2012). Establishing guidelines for the use of social media in higher education. Cutting-Edge Technologies in Higher Education (Vol. 5). Emerald Group Publishing Ltd.

Linke, A., \& Zerfass, A. (2013). Social media governance: Regulatory frameworks for successful online communications. Journal of Communication Management, $17(3), 270-286$.

Mangold, W. G., \& Faulds, D. J. (2009). Social media: The new hybrid element of the promotion mix. Business Horizons, 52(4), 357-365.

Martin, S. (2017). Stakeholder dialogue on Facebook: Findings from German, Austrian and Swiss public utilities. International Journal of Energy Sector Management, 11(2), 257-267.

McCoy, C. G., Nelson, M. L., \& Weigle, M. C. (2018). Mining the Web to approximate university rankings. Information Discovery and Delivery, 46(3), 173-183.

Mention, A. L., Barlatier, P. J., \& Josserand, E. (2019). Using social media to leverage and develop dynamic capabilities for innovation. Technological Forecasting and Social Change, 144(March), 242-250.

Mokhtar, E. S. (2017). Internet financial reporting determinants: a meta-analytic review. Journal of Financial Reporting and Accounting, 15(1), 116-154.

O’Connor, K. W., Schmidt, G. B., \& Drouin, M. (2016). Suspended because of social media? Students' knowledge and opinions of university social media policies and practices. Computers in Human Behavior, 65, 619-626.

Porumbescu, G. A. (2016). Linking public sector social media and e-government website use to trust in government. Government Information Quarterly, 33(2), 291-304.

Rahmani, A., Chen, A., Sarhan, A., Jida, J., Rifaie, M., \& Alhajj, R. (2014). Social media analysis and summarization for opinion mining: a business case study. Social Network Analysis and Mining, 4(1), 1-11.

Rutter, R., Roper, S., \& Lettice, F. (2016). Social media interaction, the university brand and recruitment performance. Journal of Business Research, 69(8), 3096-3104. 
Rylander, A., Jacobsen, K., \& Roos, G. (2000a). Towards improved information disclosure on intellectual capital. International Journal of Technology Management, 20(5-8), 715-741.

Rylander, A., Jacobsen, K., \& Roos, G. (2000b). Towards improved information disclosure on intellectual capital. International Journal of Technology Management, 20(5/6/7/8), 715.

Seigler, D. (2015). Social Media Responsiveness in the Public Sector: A Study of Social Media Adoption in Three Functional Departments of U . S . Cities, 20(1), 161

Silva, P., Tavares, A. F., Silva, T., \& Lameiras, M. (2019). The good, the bad and the ugly: Three faces of social media usage by local governments. Government Information Quarterly, 36(3), 469-479.

Stamati, T., Papadopoulos, T., \& Anagnostopoulos, D. (2015). Social media for openness and accountability in the public sector: Cases in the greek context. Government Information Quarterly, 32(1), 12-29.

Tarute, A., \& Gatautis, R. (2014). ICT Impact on SMEs Performance. Procedia Social and Behavioral Sciences, 110, 1218-1225.

Vrontis, D., El Nemar, S., Ouwaida, A., \& Shams, S. M. R. (2018a). The impact of social media on international student recruitment: the case of Lebanon. Journal of International Education in Business (Vol. 11).

Vrontis, D., El Nemar, S., Ouwaida, A., \& Shams, S. M. R. (2018b). The impact of social media on international student recruitment: the case of Lebanon. Journal of International Education in Business, 11(1), 79-103.

Vrontis, D., El Nemar, S., Ouwaida, A., \& Shams, S. M. R. (2018c). The impact of social media on international student recruitment: the case of Lebanon. Journal of International Education in Business, 11(1), 79-103.

Wilburn, K., \& Wilburn, R. (2015). Social purpose in a social media world. Journal of Global Responsibility, 6(2), 163-177. 